UDC: 339.138

JEL: M310

\title{
BRAND IMITATION IN THE MODERN SIMULACRUM MARKET VERSUS MARKETING ETHICS
}

\section{V.I. Cherenkov, S. A. Starov, I. V. Gladkikh}

St. Petersburg State University,

7-9, Universitetskaya nab., St. Petersburg, 199034, Russian Federation

For citation: Cherenkov V.I., Starov S. A., Gladkikh I. V. 2020. Brand imitation in the modern simulacrum market versus marketing ethics. Vestnik of Saint Petersburg University. Management 19 (2): 203-226. https://doi.org/10.21638/11701/spbu08.2020.204

The article presents some brand imitation issues considering the specific features of the contemporary postmodern economy where tangible items (products) are factually replaced with their simulacra (brands). The contradiction between the "spirit and letter" of the American Marketing Association Code of Ethics and the opportunities to violate its rules while branding is highlighted. It is shown that brands represented as simulacra open extensive opportunities for imitating brand leaders. A semantic ramification of terms "brand leader" and "brand imitator" in Anglophone Internet environments is represented. A typology of brand leader imitation methods with relevant examples and comments is given. The concept of "consumer confusion" is clarified and the factors determining the impact of imitated brand leaders on consumer behavior are systemized and analytically described. The legal aspects of a brand imitation strategy (proactive and reactive options) are briefly discussed. The article is supplied with relevant tables and pics.

Keywords: brand imitator, brand leader, brand semantics, brand semiotics, consumer confusion, marketing ethics, postmodern economy, proactive brand protection, reactive brand protection, simulacrum market.

\section{INTRODUCTION}

Nearly three decades of the Russian market economy have drastically changed the consumer behavior of most Russians. When the authors were university students (and were even unaware about the term "brand") only "Zhigulevskoe" (“Жигулевское”) and "Rizhskoe" ("Рижское") names of beer were available. Nowadays, just a list of the available imported and domestic brands available in Russia would take up a page. We have italized the word domestic for a reason. For instance, "Baltica” (“Балтика"), a quite valuable brand (reportedly US \$1.15 billion worth) has been owned by Carlsberg Group since 2012. And this brand represented in Cyrillic creates the phenomenon of consumer

(C) Санкт-Петербургский государственный университет, 2020 
confusion [Sertoğlu, Kavak, 2017] for those Russians who could be motivated to follow the "Buy Russian" urging slogan ${ }^{1}$. The attitude towards brands in Russia varies from ignoring to addiction.

Anyway, today a brand is a key product/service attribute that attracts customers and stimulates them to pay premium prices for branded products; it accelerates sales turnover and increases the revenue of the end vendor and the other supply chain stakeholders starting from the manufacturer. Actually, in terms proposed by J.Baudrillard [Baudrillard, 2020], a branded product market is a market of simulacra. Accordingly, the promotion of branded products by their sellers looks not quite appealing as in the latest edition of the marketing definition by the AMA (American Marketing Association)2: "Marketing is the activity, set of institutions, and processes for creating, communicating, delivering, and exchanging offerings that have value for customers, clients, partners, and society at large" [Definition of Marketing..., 2017].

It is of interest to consider and categorize the range of brand camouflaging/imitating approaches, and to assess whether the modern Russian branding meets the marketing ethics principles. The ethics definition looks consumer-friendly, but the marketers (very common for the US, a land of lawyers) have tried to protect themselves: "Marketing ethics refers to the process of applying morality principles to the execution of marketing campaigns and services. Advertising and promotion are a few of the most relevant applied marketing ethics areas and they often overlap with media ethics - which differ from that of marketing. Marketing ethics is also known as a process of generating consumer intrigue and relationships as well as stakeholder values" ([Ethics..., 2020] - italics in original).

The above-mentioned imitation of valuable brands [Zagorsky, Starov, Kiryukov, 2015] similar to the imitation of innovations [Brondoni, 2012] is a rather lucrative strategy for many consumer companies. It has long been noted [Sayman, Hoch, Raju, 2002] that a direct copying of the package appearance (design) is found in every third of the 75 fast moving consumer goods (FMCG) categories considered in the said study. A brand imitation is a slightly camouflaged reconstruction (from the package to the mass media coverage) of the reputable brand specific features (a kind of experience triggers) already known to and appreciated by the consumer to ensure a faster and cheaper promotion of the fake brand utilizing the extensive awareness and commercial value of the brand leader. Obviously, such a primitive strategy (we are not considering any marketing ethics issues so far) is usually implemented cautiously and supported by copyright and related rights legal practitioners (specifically competent in the intellectual property law in the country of origin/registration). Brand imitators tend to operate on the verge of breaking the rules, but the motivation is a quite reasonable expectation of minimizing risks and costs associated with one's independent marketing campaign. Moreover, it is difficult to pronounce a brand imitation as a brand adulteration or counterfeiting [Kotelnikova, 2008; Nagasanthi, Jaseera, 2017].

${ }^{1}$ Sounds as a possible reminiscence of the American political and economic slogan corresponding to The Buy American Act passed in 1933 by U.S. Congress and signed by President Hoover.

2 AMA definitions are to be updated every three years. 
Authenticity is considered today to be a key theme in contemporary consumer culture because contemporary branded market is overwhelmed by counterfeit substitutes [Hietanen et al., 2019]. Still, the human nature is such that there exists a rather large target market where the consumer behavior pattern is, as the great poet Alexander Pushkin put it, "Oh, it takes little to deceive me - I cannot wait to be deceived!"3. As a result, it is very easy to find surprisingly cheap replicas of famous brand watches online succedssfully searching for a consumer demand. For instance, a "Patek Philippe" is available at $\$ 100$, a "Cartier" or a "Breguete Classique Grande" — at \$200.

\section{FROM MARKET OF THINGS TO SIMULACRA MARKET AND ISSUES OF MARKETING ETHICS}

Back in Soviet times, only a few experts had heard about postmodern. Subsequently it quietly made its way into the Russian science and daily routine. As we see it, the two strongest (if not crucial) postmodern development and globalization drivers were the Bretton Woods System (1944) and the global outreach of the Internet (1980-1990s). A total virtualization of the socioeconomic activities in the most developed countries and the US in the first place (while Mr. Trump with his excellent business intuition is trying to bring the real economy back to the country) has resulted in that not goods, but financial and marketing imitations of economic benefits, institutions, manufacturing and sales are exchanged for tangible goods, build the sources of financial rent and 'status rent' $^{4}$, and initiate financial and economic crises [Buzgalin, 2018].

In the end, the postmodern economy features a high level of de-industrialization. As a result, the main products are not goods but marketing, financial, and other services necessary for selling industrial products. In the marketing exchanges, tangible goods are replaced with simulacra being brands (branded products). The consumer perceives their premium value, and is ready to pay a premium price. It is a manifestation of the brand capital phenomenon [Cherenkov, Vereteno, 2019]. A comprehensive cost vs. value branding model [Cherenkov, Vereteno, 2019] separates a real and a mental (virtual) brand value components; combined, they increase the perceived value. The consumer is ready to pay a premium price for such a premium value of branded products as perceived through the integrated marketing communication because by purchasing such branded products/services the person actually buys symbols of high profile [Buzgalin, Kolganov, 2012]. In countries of so-called "golden billion" - where the needs of the lower levels of Maslow's pyramid have long been satisfied - the needs of top levels of the said pyramid are starting to play the crucial role, and they are satisfied by simulated brands. It is notable that there is a similar situation at the metalevel of world economy (international relations) where political considerations dominate over economic ones. A shining example is the policy of anti-Russian sanctions (it is sufficient to mention the

${ }^{3}$ Pushkin A.S. Confession. 1826 (Translated by G.Gurarie). URL: https://www.tania-soleil.com/ pushkin-priznanie-na-angliiskom/ (accessed: 02.04.2020).

${ }^{4}$ Status rent is a form of compensation which could be received by officials due his/her job position. 
near billion euro penalty imposed on the French party for breaching the contract to deliver the "Mistral" helicopter carriers for the Russian Navy). The gap between the cost of a strong branded product and its price can be really huge since the price of a simulacrum is a form of illusion of the high cost of an item (virtual one) that hides its real content [Shlyakov, 2016] where the price calculated by the formula "cost plus" is its infimum.

In marketing no less than in any other specialized area of business, two main obstacles block the pathway to ethically proper conduct: ignorance and conflict. Ignorance raises the question: What is the ethically proper path to follow? Conflict asks: What price am I willing to pay to follow that path? [O’Boyle, Dawson, 1992]. These two questions separate the "to know" from the "to do" and serve to explain that knowing the moral good is not the same as doing it and show that ethical decision-making depends both on the human intellect and the human will. While preparing the AMA Code of Ethics they used fundamental pillars of ethics well-known for those who are skilled in the Art [Frankel, 1989; Backof, Martin, 1991]. However, some suggestions concerning business ethics - e.g., By routinely pursuing his/her own self-interest, a person also serves the common good through the 'invisible hand of the market' [O'Boyle, Dawson, 1992] seems disputable ones.

The AMA without equivoques is the oldest and most respected marketing organization. This is why the AMA Code of Ethics is partly reproduced herein with some comments concerning the marketers' behavior while branding (Table 1).

Comparing the data listed in the table we can see that the branding that to some extent imitates a brand leader contains an either clear or hidden, immediate or postponed violation of marketing ethics. The imitation branding categories are represented further.

As it was said [Connor, 1997] at postmodern time any reality (brand leader product) could be interpreted from a sign (brand imitator), which is, in fact, no longer related to an original reality (brand leader product). A modern customer (even more so a customer of the new Internet generation) belongs both to real and virtual worlds that drive their shopping behavior. Moreover, the shift into the virtual environment is still increasing based on the mobile device usage stats. According to Baudrillard's work Simulacra and Simulation all kinds of media today are concerned not just with relaying data and information but with interpreting our most private selves for us, making us approach each other and the world [Felluga, 2002]. Mostly it happens through the lens of these media images (brands are considered as signals manipulating the consumer behavior). Consumers in the tissue of postmodern economy do not longer acquire goods because of real estimations (experiences) but because of desires inspired by commercials and commercialized images of brands. They don't care if the brands under consideration are originals or imitations of brand leaders. The only important thing is how much their desires are inspired by these, true or copycatted, brand images.

For this reason, a product/service market is presented today as a simulacra market, where a consumer perceived brand value (both for the brand leaders and brand imitators) is more important that objectively assessed product features (if any). For over three decade simulacrum is used as an effective tool in modern brand communication for 
Table 1. Six items of the AMA Code of Ethics versus brand imitating actions

\begin{tabular}{|l|l|l|}
\hline Confrontation & Compliance with AMA Code of Ethics & Non-compliance with AMA Code of Ethics \\
\hline $\begin{array}{l}\text { Honesty vs } \\
\text { dishonesty }\end{array}$ & $\begin{array}{l}\text { Be forthright in dealings with } \\
\text { customers and stakeholders }\end{array}$ & $\begin{array}{l}\text { Buyers are often misled by imitating brand } \\
\text { leaders }\end{array}$ \\
\hline $\begin{array}{l}\text { Responsibility vs } \\
\text { irresponsibility }\end{array}$ & $\begin{array}{l}\text { Accept the consequences of marketing } \\
\text { decisions and strategies }\end{array}$ & $\begin{array}{l}\text { Mismatching characteristics of the brand } \\
\text { imitator with ones of the brand leader can } \\
\text { lead to negative consequences (especially in } \\
\text { the market of drug products) }\end{array}$ \\
\hline $\begin{array}{l}\text { Fairness vs } \\
\text { inequity }\end{array}$ & $\begin{array}{l}\text { Balance justly the needs of the buyer } \\
\text { with the interests of the seller }\end{array}$ & $\begin{array}{l}\text { Branding tools, while exaggerating the brand } \\
\text { imitator's merits, can mislead the buyer } \\
\text { about the real value of more expensive brand } \\
\text { imitator }\end{array}$ \\
\hline $\begin{array}{l}\text { Respect vs } \\
\text { disrespect }\end{array}$ & $\begin{array}{l}\text { Acknowledge the basic human dignity } \\
\text { of all stakeholders }\end{array}$ & $\begin{array}{l}\text { Imitating brand leader, while exaggerating } \\
\text { the mental part of brand imitator value, } \\
\text { can lead to ignoring the interests of such } \\
\text { stakeholders as consumers and marketing } \\
\text { intermediaries }\end{array}$ \\
\hline $\begin{array}{l}\text { Transparency vs } \\
\text { camouflage }\end{array}$ & $\begin{array}{l}\text { Create a spirit of openness in } \\
\text { marketing operations }\end{array}$ & $\begin{array}{l}\text { This contradicts the main goal of a brand } \\
\text { imitator - to disguise itself as a brand leader } \\
\text { in order to gain its market advantages }\end{array}$ \\
\hline $\begin{array}{l}\text { Citizenship vs } \\
\text { anarchy }\end{array}$ & $\begin{array}{l}\text { Fulfill the economic, legal, } \\
\text { philanthropic and societal } \\
\text { responsibilities that serve stakeholders }\end{array}$ & $\begin{array}{l}\text { to violate the economic, legal, philanthropic } \\
\text { and societal responsibilities that serve } \\
\text { stakeholders }\end{array}$ \\
\hline
\end{tabular}

Compiled from: [O’Boyle, Dawson, 1992].

creating the perceived additional value for newly designed brand imitators [Baudrillard, 1981; Floch, 1990; Bertin, 2010]. In the end, the modern market of both brand leaders and brand imitators can be considered as a simulacra market. There is a need for studies aimed at assessing the efficiency and effectiveness of imitating brand leaders by an imitator company. We believe the neuro marketing tools can be applied [Balconi, Stumpo, Leanza, 2014; Kühn, Strelow, Gallinat, 2016; Cherubino et al., 2019] to solve the issue existing on today's market: defining what and how drives consumers to decide on one brand instead of another. Such tools are better than the current marketing strategies. Therefore, both traditional and advanced branding technologies (imitating ones included) manipulate consumer behavior in favor of the seller, which, to put it mildly, does not quite correspond to so-well-declared marketing ethics.

\section{IMITATING BRAND LEADERS: SEMANTICS AND SEMIOTICS}

The branding trick while they copycat brands by imitating the trade-dress of brand leaders, such as their brand names and/or package designs, to take reputation of the latter and reduce their own marketing costs [Van Horen, Pieters, 2012] is well-known not only 
among marketers but in common public. The brand imitation strategy is an explicit/ implicit infringement of rights of an owner of the original brand leader and the result is a false consumer perception of additional value of a brand imitator. The company operating with the said brand imitator receives or expects to receive an augmented premium price per item and/or increased market share. First of all, to reduce uncertainty in terms, we should sort out the definitions since some branding term definitions are not conventional. Any brand imitation on a simulacra market means the presence of more valuable brands that a company imitator wants to simulate. As specified in the online Cambridge Dictionary, a brand leader is a brand that has the largest share of sales in its market compared to other brands in the same market. The largest share of sales is the very driver that makes companies to imitate brand leaders since the latter have been maintaining competitive edge in their product categories and have a strong influence on other brands [Chang, Ko, 2014]. The 7 top global brands - namely, Apple, Google, Amazon, Microsoft, Coca-Cola, Samsung and Toyota [Best Global..., 2019, p.11] - make consumers' perceptions of corresponding items as belong to the class of "cutting edge device" and/or "must have" [Kunz, Schmitt, Meyer, 2011]. As it has been noted [Chang, Ko, 2014], brand leaders may play a significant role as exemplars and positively influence other brands in visible (e.g., enriching product features) and invisible forms (e.g., firms' vision of goals versus corporative responsibility and/or product sustainability).

It seems advisable to start with an understanding of the pairs of terms that reflect the relationship between the original brand and its copy in the context of the imitative branding strategy. For this purpose, an analysis of the relevant English literature on branding was carried out, the results of which are shown in Table 2.

Table 2. Multiple semantic representation of "brand leader" and "brand imitator" concepts

(number of Google-responses on requests to search for corresponding terms, January 2020)

\begin{tabular}{|c|c|c|c|c|c|c|}
\hline Brand leader $^{\mathrm{A}}$ & $\begin{array}{c}\text { Pioneer } \\
\text { brand }\end{array}$ & $\begin{array}{c}\text { Innovator } \\
\text { brand }\end{array}$ & $\begin{array}{c}\text { Original } \\
\text { brand }\end{array}$ & $\begin{array}{c}\text { Contributor } \\
\text { brand }\end{array}$ & $\begin{array}{c}\text { High-quality } \\
\text { brand }\end{array}$ & Strong brand \\
\hline 815000 & $352000^{\mathrm{C}}$ & 36300 & $7650000^{\mathrm{C}}$ & 8330 & $5570000^{\mathrm{D}}$ & $4140000^{\mathrm{D}}$ \\
\hline $\begin{array}{c}\text { Brand } \\
\text { imitator }^{\mathrm{B}}\end{array}$ & $\begin{array}{c}\text { Follower } \\
\text { brand }\end{array}$ & $\begin{array}{c}\text { Knock-off } \\
\text { brand }\end{array}$ & $\begin{array}{c}\text { Lookalike } \\
\text { brand }\end{array}$ & $\begin{array}{c}\text { Borrowed } \\
\text { brand }\end{array}$ & $\begin{array}{c}\text { Copycat } \\
\text { brand }\end{array}$ & $\begin{array}{c}\text { Parasite } \\
\text { brand }\end{array}$ \\
\hline 57500 & 52400 & 284000 & 3500 & 14200 & 47900 & 19500 \\
\hline
\end{tabular}

N o t e s: A - it could be somewhere represented as "brand leader" (135 000) or "leader's brand" (5 380); B - it could be somewhere represented as "brand imitator" (188 000) or "imitator's brand" (7); C - it is suspected these estimations are distorted due to the fact the number of Google-responses on requests "pioneer brand" and "original brand" also includes responses induced by corresponding brand names on the global market - Pioneer and Original, respectively; D - these adjectives — "high-quality" and "strong" - are too general that be included as elements while constructing branding terms.

C o m piled from: [Alpert, Kamins, 1994; Phau, Prendergast, Chuen, 2001; Hoffler, Keller, 2003; Language Variation..., 2003, p. 281; Morhart, Herzog, Tomczak, 2009; Chilet, Chen, Lin, 2016; The Ultimate Brand Protection..., 2020]. 
As a result, from the entire array of revealed pairs of terms, "brand leader" and "brand imitator" have been selected and are used throughout this article from the very beginning. Despite the fact the term "leader brand" is found on the Internet more than twice as often as the term "brand leader" we suppose the latter is semantically best suited to the purpose of this article.

\section{TYPOLOGY OF IMITATING BRAND LEADERS}

There are different types of brand imitation on B2C markets: piracy, counterfeiting, gray marketing goods and imitation of brands [Lai, Zaichkowsky, 1999]. However, within this study we considered so-called semi-legal brand imitations that could be found in marketing literature [Finch, 1996; Zaichkowsky, Simpson, 1996; Howard, Kerin, Gengler, 2000; Le Roux, Bobrie, Thébault, 2019]. As our analysis showed, the brand leader imitation approaches can be categorized based on the following: 1) imitation by hallmarks divided into: a) semantic-phonetic; b) semiotics; c) functional (Table 3), and 2) sensual imitation. The imitation by hallmarks is an obvious copying of a lead brand in a certain product category. Brand imitators usually copy its features virtually a lettre.

Let us have extra explanations about the semiotic brand imitation [Veg-Sala, Roux, 2014]. Though studying the psychological aspects of ad/package perception, brand imitators change secondary elements of the visual image of brand leaders (generated by

Table 3. Hallmarks of imitative branding strategies

\begin{tabular}{|c|c|c|}
\hline Type & Description & Examples \\
\hline \multirow{2}{*}{ 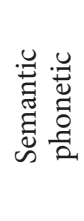 } & \multirow{2}{*}{$\begin{array}{l}\text { Making phonetic associations with the name of brand leader. A } \\
\text { partial (to avoid copyright infringement charges) copying of the } \\
\text { brand name letters. The name is changed is such a way that the } \\
\text { consumers can still be phonetically confused ("inner sense"), } \\
\text { feel the positive emotions associated with the brand leader, and } \\
\text { expect an added value }\end{array}$} & Original $\Rightarrow$ Copycat \\
\hline & & $\begin{array}{l}\text { Nivea } \Rightarrow \text { Livea } \\
\text { Adidas } \Rightarrow \text { Abibas } \\
\text { Blend-a-med } \Rightarrow \text { Bel-a-med }\end{array}$ \\
\hline 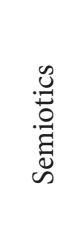 & $\begin{array}{l}\text { A partial (to avoid copyright infringement charges) copying } \\
\text { of colors, fonts, marking, and packaging belonging to a brand } \\
\text { to create a look-alike of the brand leader logo/product design. } \\
\text { This kind of imitation is mostly implemented as an intentional } \\
\text { copying the packaging design/style. Unscrupulous competitors } \\
\text { try to make products with the appearance that trigger false } \\
\text { associations with the brand leaders }\end{array}$ & $\begin{array}{l}\text { See Figure } 1 \\
\text { See Figure } 2\end{array}$ \\
\hline \multirow[t]{2}{*}{ 祍 } & $\begin{array}{l}\text { Copying (with no obvious copyright infringement) the } \\
\text { features of the packaging of brand leader that are associated } \\
\text { with an additional consumer value such as convenient } \\
\text { usage, consumption, or storage; easy stockpiling; economical } \\
\text { application (built-in dispensers), "smart" labeling and product } \\
\text { identification }\end{array}$ & $\begin{array}{l}\text { For example, these are tailor- } \\
\text { made packaging materials } \\
\text { with certain strength and } \\
\text { bactericide properties; } \\
\text { "green packaging" [Jedlička, } \\
\text { 2009] }\end{array}$ \\
\hline & Possible subsequent use & Tikkurilla paints in buckets \\
\hline
\end{tabular}


brand imitators) while preserving the key appearance that send the same semiotic signals (symbols/signs) to consumers as the products under brand leaders do. The brand color is really important (there is a famous story of "separation by red color" between Coca Cola and Pepsi [Labrecque, Milne, 2012]). It has long been proved that the average consumer looks at a product from 1 to 5 meters away. In this case, people (not only visually impaired) see not fine packaging elements but just color spots that actually serve to identify the branded product [Uskov, 2001]. A brand imitator also produces a semiotic effect by a combination of packaging color and shape, and the font. Combined, they deceit the consumers and distort their perception of the brand imitator though generating subconscious associations with the brand leader. For instance, a well-known liquid detergent "Fairy" produced by $\mathrm{P} \& \mathrm{G}$, always aggressively advertised, and now striving to become the sustainability brand [Procter \& Gamble..., 2019] ${ }^{5}$ has been imitated by the brand imitator "Mary" (Figure 1a). This imitation was created due to such similarities as the easily recognizable red cap of bottle, image of liquid drop, and similar inscription of brand name in red on a specific shape of bottle.

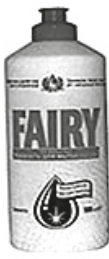

a) "Fairy" (brand leader) versus "Mary" (brand imitator)

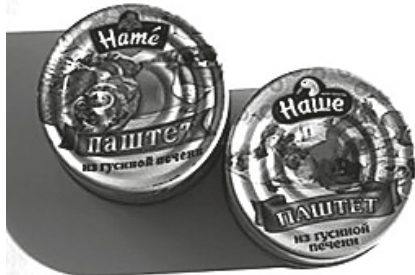

b) "Hame" (brand leader) versus "Наше" (brand imitator)

Figure 1. Semiotic brand imitation

Yet another example of such a semiotics brand imitation (the authors consider it as a semantic confuse) is the claim by the brand "Hame" owner (Czech Republic) against company Ruzcom (Russia). Ruzcom makes a line of meat paste and sausages under the brand "Наше" (inscription in Cyrillic). The overturned "ш" letter (Cyrillic) makes the brand names visually identical (Figure 1b). Still, the Russian Federal Antimonopoly Service ordered Ruzcom to discontinue the brand "Наше". The reason: consumers confuse pastes and sausages under the brand "Hawe" with the mentioned Czech brand.

Sensual brand imitation is a special and more sophisticated strategy for a brand leader imitation. It is based on the consumer's unconscious reaction to symbolic signals sent by the brand imitator, centered on his/her self-reference criterion [Cateora, Graham, 1999, p.12-14]. It is assumed that a potential consumer gets a feeling of not quite clear but

${ }^{5}$ Procter \& Gamble launches in Russia the sale of Fairy in a bottle made of oceanic plastic Philanthropist 13.11.2019. URL: https://philanthropy.ru/novosti-organizatsij/2019/11/13/82441/ (accessed: 18.04.2020).

${ }^{6}$ Paste "Наше" will leave the market Next Brands. (In Russian). URL: https://www.next-brands.com/ pashtety-nashe-ujdut-s-rynka/ (accessed: 02.04.2020). 
emotionally convincing similarity of the perception of brand imitator as being identical to the brand leader having its additional value. Such a sensual imitation is comprehensive and generates a range of "hints" to the value of brand leader that to some extent match the fictional reality that integrates allusions to the brand imitator. And, what is most important, the expected branded product ownership [Cherenkov, Vereteno, 2019] is associated with the possession of everything available on the top layers of Maslow's hierarchy. It should be noted that such a sensual imitation is practically not punishable by any IP laws. The point is that it is not direct copying of obvious identifiers, but a sophisticated manipulation with the mental construct in the consumer subconscious mind.

An example of a sensual imitation of brand leader is presented by a very common product category: Kracks chips from the Food Empire. Even the most scrupulous expert cannot unambiguously declare it to be an imitation of the Pringles brand designed and owned by the Procter \& Gamble. But comparing two packs corresponding to the said brands (Figure $2 a$ ) invokes similar associations in most customers that serve as a purchasing trigger both for the brand leader and the brand imitator. Additionally, one can compare two kinds of imitations for the famous "Nutella" (chocolate-and-nut paste) brand leader by a pair of brand imitators - "Cremosa" and "ChocoCrema", respectively (Figure 2b). So, in the world of brand imitators an explicit semantic/semiotic imitation (a combination of sign/symbol signals of different nature) and an implicit sensual imitation (inducing mental constructs previously present in the consumer's mind) coexist.
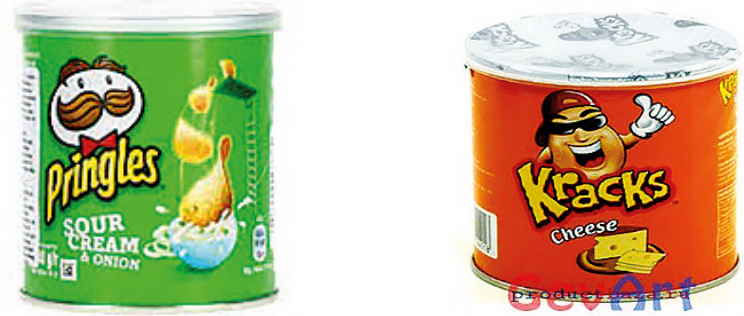

a) "Pringles" (brand leader) versus "Kracks" (brand imitator)
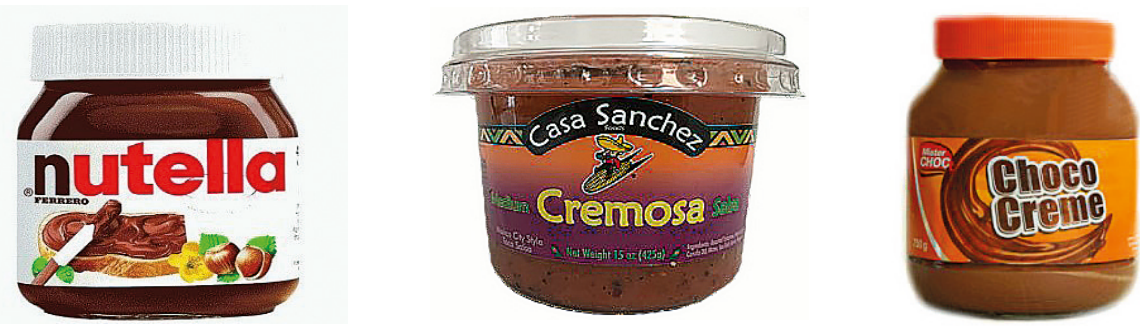

b) "Nutella" (brand leader) versus "Cremosa" and "Choco Crème" (brand imitators)

Figure 2. Sensual brand imitation 


\section{BRANDING STRATEGIES FOR IMITATING BRAND LEADERS IN DIFFERENT PRODUCT CATEGORIES}

When creating a brand imitator, the management of imitator company should (with the assistance of IP lawyers) thoroughly analyze pros and cons of its brand leader imitation strategy. Usually, such a strategy masterfully protects the imitator company from any IP infringement charges because "counterfeit, on a strict definition, is something that is forged, copied or imitated without the perpetrator having the right to do it, and with the purpose of deceiving or defrauding" [Chacharkar, 2013, p.iii]. It is noted that for a brand leader it is not that easy to sue and gain a case against an imitator company because in the academic and business sources they write that manufacturers will take legal action against each other when they believe their trademarks or trade dress have been infringed upon, but they are reluctant to take legal action when retailers undertake the same copycat activity [Collins-Dodd, Zaichkowsky, 1999]. In addition to the benefits of brand imitation mentioned above, it is necessary to highlight a few disadvantages of the said strategy for brand imitating companies [Zagorsky, Starov, Kiryukov, 2015]:

- in contrast to a brand leader, the brand imitator usually lacks personality and additional value, that can push away its prospects;

- brand imitator's lack of personality and insufficient additional value hampers the brand loyalty-building;

- insufficient study of the possibility of filing a lawsuit regarding the copying of a brand leader may entail (according to the court verdict) a ban on the use of the brand imitator, imposition of a fine and payment of legal costs.

Nevertheless, brand imitation strategies are quite popular, and the companies that use them (their behavior patterns are presented below) can be categorized as follows [Collins-Dodd, Zaichkowsky, 1999]:

- small and medium manufacturers trying to imitate the market leader products;

- large manufacturers trying to imitate successful innovative products (often invented, designed and embodied at the level of prototype by small R\&D companies);

- retail chains imitating products from the national-wide manufacturers under national brands.

Small and medium manufacturers. The key reason for imitating brand leaders is the lack of financial resources for their own branding efforts.

Large manufacturers. These companies, on contrary, have sufficient resources for any (either original or imitative) branding in order to: 1) faster securing a market share in the specific product category; 2) using brand imitators in a "war of competing brands" to undermine the market standing of their direct competitors up to a complete destruction (shake-out) of the competing brand. The latter kind of imitative branding is expressively named "vampirism" [Kolesnik, Fukolova, 2003]. For example, Russian company Neva Cosmetics (its product is "Новый жемчуг" toothpaste - "New Pearls") (Figure 3b) has 
a)

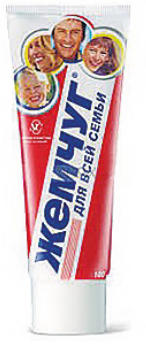

б)

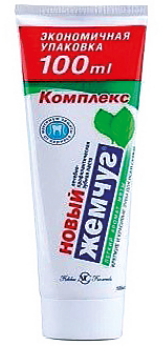

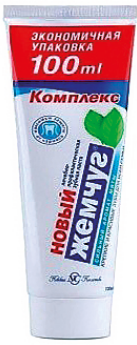

Figure 3. Brand imitator "New Pearls" ("Новый жемчуг”) launched by the large company (Svoboda Cosmetics Corporation) as the absolute winner of original brand "Pearls" (“Жемчуг”)

copied the name and packaging of "Pearls" (“Жемчуг”) toothpaste (earlier produced by Svoboda Cosmetics Corporation) (Figure 3a).

As of today, brand "New Pearls" is one of the brand leaders on the toothpaste market while brand "Pearls" has lost its market share and almost disappeared from the shelves. It should be noted that for large companies the purpose of brand imitation is not only getting an additional value at the competing brand's expense but be a competitive tool to beat a competitor and expand its market share.

Retail chains. For these retail market entities, the primary purpose of brand imitation is promoting its private brands (labels). Recall that an accessible and reliable source defines the private (label) brand as "a good that is manufactured for and sold under the name of a specific retailer" [Private brand..., 2019] (usually, retail chains). Retail chains consider private brands as a very important competing tool, and a certain perceived by consumers guarantee of the product quality since the accountable party in the supply chain (retailer) is closer to the consumer than any market intermediaries or manufacturers. The latest presented Nielsen 2018 data has demonstrated that market share for products under private label increased last year (2017) in 12 of 19 countries were under consideration, and reached up to $30 \%$ or above in 17 countries [Private label..., 2018]; in particular, United Kingdom, Germany, Belgium and Portugal - more than $40 \%$. Even more inspirational figures concerning private label applications are observed in Russian B2C-market. Retail chains promote their private labels that imitate the main appearance of national brand leaders [Bernitz, 2009]. These brand imitators (copycats or look-alike brands) are common worldwide; during the last decades, they are extensively used in Russia as well [Starov, Kiriykov, 2016; Starov et al., 2016].

When private labels are brand imitators, they are often products under an (umbrella) brand of the retail chain or a specific name owned by the retail chain, but they nearly exactly copy the design of the brand leaders owned by the manufacturing suppliers (Figure 4).

In most cases an imitator of private label brand offers mid-price and acceptable quality products with packaging similar to the packaging of products sold under the copied brand leader of a national-wide manufacturer. In this case, such a private brand 

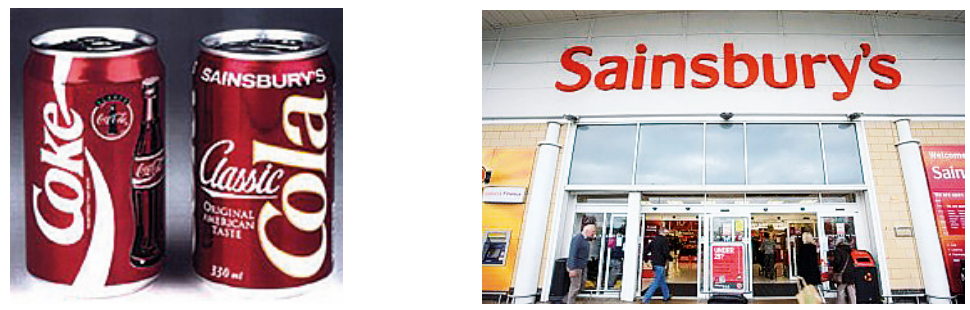

Figure 4. Brand imitator (right can) Sainsbury's Classic "Cola" together with original brand leader "Coke" (left can); Sainsbury's supermarket entrance is presented for completeness

imitator is an alternative to a manufacturer's brand leader [Burt, Davis, 1999]. On the store shelves, private brand imitators are usually placed next to the manufacturer's brand leader products to let the customer compare prices and make a purchasing decision in favor of brand imitator. It is a kind of promotion for private brand imitators. As a result, customers attracted by comparable quality at lower price opt for the brand imitators. Private brand imitators generate extra revenue for retail chains, despite the price being up to $25 \%$ lower than the price of the brand leader products [Jary, Wileman, 2016].

\section{IMITATING BRAND LEADERS IN DIFFERENT PRODUCT CATEGORIES}

As a rule, most brand imitators operate on the FMCG market where the consumer is not strongly involved in making a purchasing decision. On the contrary, in the premium market segments, the purchasing requires the deep involvement of the customer, and using brand imitators is not so efficient and attractive. It is believed that food brands are copied most. One of successful food brand imitation examples is a lollipop sold under the rather frivolous name "Licker Sucker" released by the candy factory Russian Menshevik ("Русский меньшевик") in 2001 (Figure 5b). The packaging was nearly an authentic replica of the Spanish brand "Chupa Chups", designed by Salvador Dali in 1969 (Figure 5a).

a)

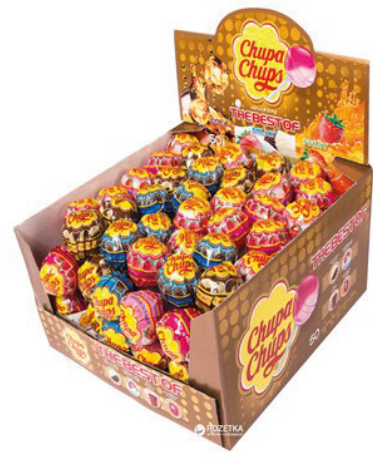

b)

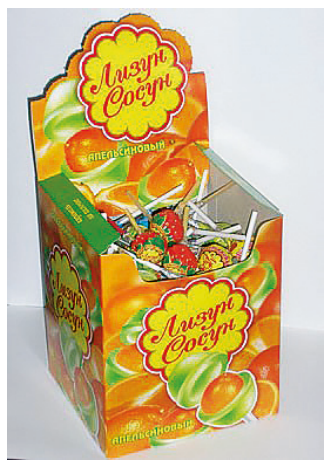

Figure 5. Russian brand imitator "Licker Sucker" that defeated the Spanish brand leader "Chupa Chups" in the Russian candy market 


\begin{tabular}{c|c|c}
\hline $\begin{array}{c}\text { Product } \\
\text { category }\end{array}$ & $\begin{array}{c}\text { Brand } \\
\text { leader }\end{array}$ & $\begin{array}{c}\text { Brand } \\
\text { imitator }\end{array}$ \\
\hline Liquors & $\begin{array}{l}\text { Brand leader } \\
\text { vrand imitator case }\end{array}$ \\
Lawsuit: Glavspirttrest, Ltd. vs. Valuisky \\
Liquor Company, Open JSC. Subject: \\
violation of Article 14, Federal Competition \\
Act concerning the illegal use of trademark \\
similar to the registered trademark owned \\
by the Glavspirttrest, Ltd. service marks on \\
the "Green Mile" vodka bottles
\end{tabular}

Figure 6. Examples of phonetic/semiotic imitations of brand leader

In 2001, the owner of Russian Menshevik, claimed that his brand "Licker Sucker" without any active and expensive promotion had won about $30 \%$ of the Russian lollipop market having pushed brand leader "Chupa Chups" [Kashulinsky, Kovalenko, 2002].

There are also other "leader/imitator brand" couples such as "Rexona" (brand leader) and Roxana (brand imitator) in the deodorant product category; "Taft" (brand leader) and "Taff" (brand imitator) in the hair styling aids product category. The same brand couples are easy revealed in product categories of the popular OTC drugs and spirits (Figure 6).

Customer perception of brand imitators: consumer confusion. As brand imitators are promoted, the customer (even more so senior customers) can be confused [Mitchell, Walsh, Yamin, 2005] resulting in buying the brand imitator instead of the brand leader. A special survey by the Russian Public Opinion Research Center (VTsIOM) reports that $88 \%$ of consumers can easily mistake an brand imitator package for the brand leader package or believe that a product just slightly different in its appearance comes from the same manufacturer [Zagorsky, Starov, Kiryukov, 2015]. A consumer confusion with brand similarity can be defined as a lack of understanding and potential alteration of a consumer's choice or an incorrect brand evaluation caused by the perceived physical similarity of products or services [Mitchell, Walsh, Yamin, 2005]. A brand confusion (brand leader versus brand imitator) refers to an inferential processing error that leads a consumer to unknowingly form inaccurate beliefs about the attributes or performance of a less-known brand based on a more familiar brand's attributes or performance [Foxman, Berger, Cote, 1992]. A subconscious perception of the brand value is interpreted as filling the gaps in the available branded product specifications to be assessed by consumers, and making a choice out of a predefined number of options [Balabanis, Craven, 


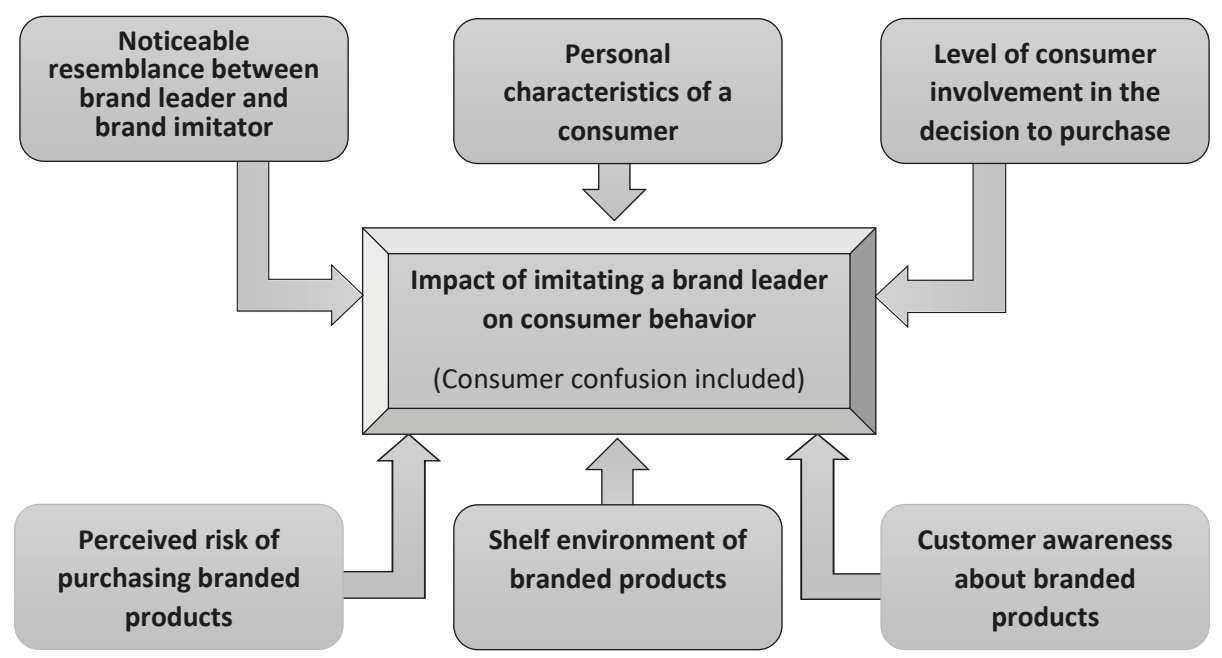

Figure 7. Factors defining the impact of imitating a brand leader on consumer behavior

1997]. The perception depends on the similarity between the brand leader and the brand imitator. Such similarity is assessed $a d$ hoc and subjectively. Still, there is a certain mean value for consumer groups with similar personality traits. Objectively, the same range of imitated properties of brand leader affects different consumer groups differently [Walsh, Mitchell, 2005; Walsh et al., 2010]. The key groups of factors defining the impact of imitating a brand leader on consumer behavior are described below (Figure 7).

Noticeable resemblance between the brand leader and the brand imitator. The general concept of the brand imitation effects is quite trivial: the more similar the brand imitator and the brand leader are, the higher the probability of confusing the consumer by the brand imitator as they select a product considering all its features [Foxman, Berger, Cote, 1992; Walsh, Hennig-Thurau, Mitchell, 2007] (e.g., prices). The "consumer confusion" category has long been studied by the consumer behavior researchers beginning from [Friedman, 1966]. It can be defined as such a consumer's state of mind has been created during a buying decision making the said process an ambiguous and non-stable one characterized by the inability to finalize the choice of brand. According to main goals of the present paper two facets of the brand consumer confusion are considered herein [Miaoulis, D’Amato, 1978]: 1) brand similarity as an important cause of brand confusion and 2) brand (trademark) infringement [Diamond, 1973]. As it was defined [Diamond, 1973, p. 45] the brand similarity confusion occurs when a brand imitator "...so resembles the mark in appearance, sound, or meaning that a prospective purchaser is likely to be confused or misled". So, the brand imitator and the brand leader similarity induced the range of consumer emotions identical to that induced by the brand leader. If at the given moment the consumer does not have the brand leader in sight (while the attractive price is clearly visible), it increases the probability of consumer confusion, and the consumer may opt for the brand imitator [Kapferer, 1995]. 
Personal characteristics of a consumer. The extent of consumer confusion, the probability and the period when he/she may mistake a brand imitator for a brand leader depends inter alia on his/her personal characteristics. The most vulnerable [Walsh, Mitchell, 2005; Walsh et al., 2010] are such high-risk groups as females, senior citizens, and low-educated persons.

Level of consumer involvement in the decision to purchase. Involvement is a motivational variable in consumer behavior that can be used to describe the level of consumer interest, search, or complex decision making in the marketplace [Zaichkowsky, 2010]. A consumer's level of involvement can be used as a segmenting variable to further target the market by brand managers. Low consumer involvement implies inertia, and high involvement implies a great deal of activation and it is found to influence consumer decision making and interactive communications. Deep involvement is associated with durables and luxury items. It means that consumers are ready to spend more time and "emotional efforts" on relevant information search and assessing the options of the said items [Browne, Kaldenberg, 1997]. As to FMCG, the buying process is usually simplified [Browne, Kaldenberg, 1997]. It was noted [Penz, Stöttinger, 2003] that consumers are more likely to distinguish brand imitators from brand leaders in product categories requiring higher involvement.

Customer awareness about branded products. Brand awareness refers to whether consumers can recall or recognize a brand, or simply whether or not consumers know about a brand [Keller, 2008]. Brand awareness affects consumer decisions concerning alternative brands, especially for low involvement packaged FMCGs. Brands that consumers know could be more likely included in consumers' considerations [MacDonald, Sharp, 2000]. Consumers with various knowledge of the branded product specifications and properties have various chances to buy the brand leader, not a brand imitator [Alba, Hutchinson, 1987; Laroche et al., 2003].

Perceived risk of purchasing branded products. The most lapidary definition of perceived risk is based on consumers' subjective expectations of a loss and means that a consumer will produce consequences which he/she assess as at least likely to be unpleasant [Sweeney, Soutar, Johnson, 1999]. The purchasing risk as perceived by the consumer is generated not only through the negative expectations due to incomplete features of the low quality of the product, but also through the purchase evaluation by his/her community members [Dick, Jain, Richardson, 1995]. The nature of the perceived consumer risk when making a "brand leader vs. brand imitator" decision is similar to the "product under private label (PPL) vs. product under manufacturer's brand (PMB)" decision, and in many instances, a PPL is perceived by the consumer as a product under a less valuable brand that the PMB [Nenycz-Thiel, Romaniuk, 2011]. Finally, consumers experience a financial risk when buying a brand imitator: there is a great uncertainty regarding the quality of brand imitator, and there may be issues with the quality claims and return/ refund [Cordell, Wongtada, Kieschnick, 1996]. It was proved [Huang, Schrank, Dubinsky, 2004] that the total purchase risk reduces as the consumer awareness about the 
brand properties is expanded (including, for instance, the brand imitator value for his/ her community members: the conformism effect).

Shelf environment of branded products. A brand imitation strategy shall consider the product context (shelf environment). On one hand, the presence of a brand imitator on the shelve with relatively cheap products would not yield the market effect expected by the imitator. On the other hand, placing a brand imitator on the same shelf with the brand leader immediately reveals to the consumer the imitation and the consumer confusion intent [D'Astous, Gargouri, 2001]. In this case, there is an implicit or explicit issue of whether imitating brand leader is ethical since along with a semi-legal use of someone's else IP that infringes on the rights of the imitated brand owners, the consumer interests are also affected because they are taken to consumer confusion.

\section{SOME LEGAL ASPECTS OF THE BRAND IMITATION STRATEGIES}

In today's market economy, despite multiple codes of ethics, unfair competition practices are still common. With the rise of international trade (e-commerce included), international and cross-border conflicts in trademark and unfair competition law become more and more important. The basic principle to define an ethical nature of competition is a subjective one: our mental assessment whether the competition between people/companies is arranged based on the rules of honor, honest practices and fair business habits or not. Competing companies from time to time violate the legislation: illegally and semi-legally they copycat or imitate brand leaders. As a result, brand leader owners lose their consumers (and the market share), and with the lowquality of products made by a licensee under a legally obtained brand (a brand license agreement), the brand owner suffers both financial losses and damage to reputation caused by the possible devaluation of the licenser's brand. If the reputation of a brand leader is damaged, the consumer is less likely to trust in the "brand promise" and that the so-called "contract of expectations" could be satisfactorily met. Once there was a survey in the UK [Collins-Dodd, Zaichkowsky, 1999]. It showed that $51 \%$ of employees of manufacturers answered that they revealed the appearance of corresponding retailers' private brands understood as brand imitators. Besides, 41 cases of such an imitation had resulted in their companies' sales drops. This rather common phenomenon of unfair competition has required the development of protective strategies. Note that the prevailing viewpoint today is that brand protection is relevant not only for the brand owner but for the consumers as well. The primary objective of a brand protection strategy, according to research, is to keep consumers safe [The future of online brand protection..., 2019]. The latest computer technology advances drastically increased the efficiency of brand protection strategies through incorporating cybersecurity best practices [Chicada, 2019]. Generally, the trademark protection strategies can be categorized as: 1) proactive; and 2) reactive.

According to the research and field experience [Wilson, Kinghorn, 2016], proactive brand protection strategies are considered as the most effective ones due to their expected 
proactive and holistic nature. Main instruments of proactive brand protection strategies are in the field of law concerning the protection of intellectual property.

The very first step in the development of proactive brand protection strategies consists of defining the vulnerable zones of the brand design to be protected, such as: brand name, logotype elements, and color (combinations of colors) specific for the brand under consideration. It is believed, that the diversity analysis can be applied for a number of brand management activities, such as reputation management, competition analysis, market analysis, and sentiment analysis [Hasan et al., 2011]. There have been cases of using it for proactive protection of brand property rights. Identification of a number of brand-specific features defines its uniqueness and assigns it to the brand creator. For example, Uskov and Partners, a Russian company, has long mastered this approach [Uskov, 2001]. A meticulous vulnerability analysis for a brand takes two to three months to simulate the imitator's actions to identify what brand features are most vulnerable to imitation. It is analytical proactive protection.

Naturally, there is also legal brand protection. This study shows just a few examples of it, which is not a complete representation of such an IP protection strategy. To protect a trademark, there is the worldwide-known Madrid Convention: The International Trademark System [Madrid...], an international legal framework for such protection. In Russia, the trademark definition and protection are regulated by the Civil Code of RF (Part IY) [Civil Code...]. The International Classification of Goods and Services for the Purposes of the Registration of Marks or the Nice Convention [Nice Agreement...] serves to identify the subject of IP protection. A so-called umbrella protection of brand leaders is believed to be efficient. It embraces multiple product/service categories as applicable to a single trademark (brand name), and its individual features (logo, color, etc.). Such protection has a limited lifespan and can be prematurely terminated if a registered trademark is not actually used [Zagorsky, Starov, 2015].

The proactive protection of brand leaders is not limited to the said trademark protection. There are other kinds of IP items to be protected. The Russian legislation (Civil Code of RF, Article 1353 "National Registration of Inventions, Utility Models and Industrial Designs") follows periodically upgraded international documents; e.g., The Hague System for the International Registration of Industrial Designs [Hague...]. Lawyers experienced with international IP protection legislation are required to develop comprehensive legal protection of brand leaders. Let us consider an example of such protection for just one commonly known product: a family of "Ritter Sport" square chocolate bars (Figure 8).

Among other matters, the very square shape of the bars is protected in Germany as an industrial design (quoted after: [Zagorsky, Starov, Kiryukov, 2015]).

Reactive brand protection strategies kick into action once an infringement of brand ownership happens. Contrary to proactive brand protection strategies, reactive ones try to identify all relevant brand ownership infringements and make relevant countermeasures, but after an incident occurs. Having learned about a brand imitator appearance, the brand leader owner (or a legal brand leader user - brand leader licensee) should 

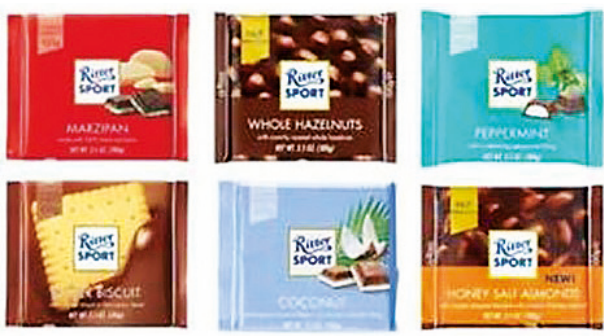

Figure 8. The square shape of the "Ritter Sport" bars is protected in Germany as an industrial design

immediately file a complaint to its national authority. In Russia, a common reactive strategy is filing a complaint with the Chamber of Patent Disputes (Russian Agency for Patents and Trademarks). Still, the Russian Federal Antimonopoly Service (FAS) expects substantial proofs that after releasing a clone brand the original brand owner suffers a significant decline in the branded product sales and customer outflow especially when both companies operate in the same field or in the same territory [Zagorsky, Starov, Kiryukov, 2015].

Finally, let us consider an example of the said reactive strategies. In 2001, Metatabac (“Метатабак") factory (Podolsk, Russia) released two brands of cigarettes ("Baltica 3" and "Baltica 9") with a slightly amended logos of the Baltica's beer (Figure 9a) on the cigarette packs (Figure 9b).

a)

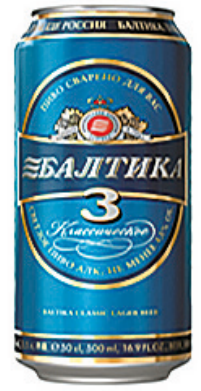

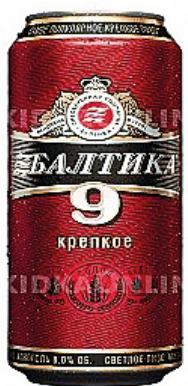

б)
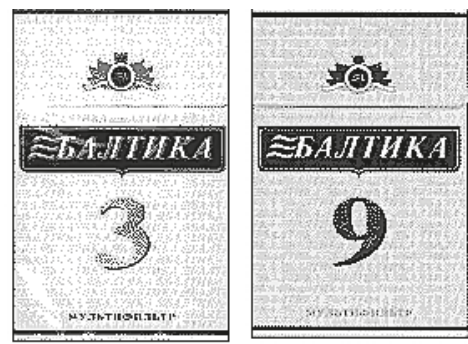

Figure 9. The case of illegal using the Baltica beer logo on the packs of cigarettes produced by a company imitator

Then, Baltica Brewery sued and won the case in every hearing because Baltica had been registered as a trademark and as four name/design combinations. The court ruling made Metatabac at its own expense to publish announcements about the termination of the said illegal cigarette production under the brand imitator, and the entire batch of cigarettes was destroyed by the court verdict (quoted after: [Zagorsky, Starov, Kiryukov, 2015]). 


\section{CONCLUSION}

The key finding of the research presented herein is that in a postmodern economy the consumer's decision to buy is governed not so much by the actual product properties as by the brand images (simulacra) used to market them. For this reason, they can say that a market of tangible products has been factually transformed into a simulacra market. This phenomenon, despite violating the extensively declared marketing ethics rules, results in the proliferation of imitations of valuable brand leaders that confuses the consumers. The study categorizes brand imitation methods into semantic-semiotic and sensual types that make it difficult to prove the very fact of imitation and in that differ from obvious counterfeiting. Imitation of brand leaders brings a perceived (often doubtful) additional value to the brand imitators.

This unethical trick gives to imitating companies a chance to reduce their costs and risks in comparison with their own hypothetical branding. It is revealed that imitation of brand leaders is used in the market by imitating companies of any size. However, for large companies, such an imitation could be considered as a part of their competitive toolkits. There are both proactive and reactive brand protection strategies permitting to protect the trademark as a whole or its individual elements. Despite the IP protection legislation in force in every country and applicable to brand protection, proactive strategies based on creating brands with unparalleled features (difficult or too expensive to imitate) are preferable.

\section{References}

Alba J., Hutchinson W. 1987. Dimensions of consumer expertise. Journal of Consumer Research 13 (4): 411-454.

Alpert A.F., Kamins M.A. 1994. Pioneer brand advantage and consumer behavior: A conceptual framework and propositional inventory. Journal of the Academy of Marketing Science 22 (3): 244-253.

Backof J. F., Martin Ch. L., Jr. 1991. Historical perspectives: Development of the codes of ethics in the legal, medical and accounting professions. Journal of Business Ethics 10: 99-110.

Balabanis G., Craven S. 1997. Consumer confusion from own brand lookalikes: An exploratory investigation. Journal of Marketing Management 13: 299-313.

Balconi M., Stumpo B., Leanza F. 2014. Advertising, brand and neuromarketing or how consumer brain works. Neuropsychological Trends 16 (November): 15-21.

Baudrillard J. 1981. Simulacres et Simulations. Paris: Editions Galilée.

Baudrillard J. 2020. Consumer Society. AST. (In Russian)

Bernitz U. 2009: Misleading packaging, copycats and look-alikes: an unfair commercial practice? In: A.Ezrachi, U. Bernitz (eds.). Private Labels, Brands, and Competition Policy: The Changing Landscape of Retail Competition. Oxford; 217-234.

Bertin E. 2010. Le vertige de la différenciation, tropisme de la pensée stratégique dans le champ du marketing et de la communication? Communication 28 (1). URL: http://communication.revues. org/2056 (accessed: 14.03.2020).

Best Global Brands 2019 Iconic Moves 2019. URL: https://www.interbrand.com/wp-content/ uploads/2019/10/Interbrand_Best_Global_Brands_2019.pdf (accessed: 02.02.2020). 
Brondoni S.M. 2012. Innovation and imitation: Corporate strategies for global competition. Symphonya. Emerging Issues in Management 1: 10-24.

Browne B., Kaldenberg D. 1997. Conceptualizing self-monitoring: Links to materialism and product involvement. Journal of Consumer Marketing 14 (1): 31-44.

Burt S., Davis S. 1999. Follow my leader? Lookalike retailer brands in non-manufacturer-dominated product markets in the UK. International Review of Retail Distribution and Consumer Research 9 (2): 163-185.

Buzgalin A. V. 2018. The key to understanding the contradictions of the modern economy (to the $200^{\text {th }}$ anniversary of the birth of Karl Marx). Terra Economicus 16 (2): 83-98. (In Russian)

Buzgalin A. V., Kolganov A. I. 2012. The Market of Simulacra from the Perspective of Classical Political Economy. Philosophy of Economy (2): 153-165. (In Russian)

Cateora Ph. R., Graham J.L. 1999. International Marketing. Irwin: McGraw-Hill.

Chacharkar D. Y. 2013. Brand Imitation, Counterfeiting and Consumers, Consumer Education. New Delhi: New United Process.

Chang Y., Ko Y.J. 2014. The brand leadership: Scale development and validation. Journal of Brand Management 21 (1): 63-80.

Cherenkov V. I., Vereteno A. A. 2019. Brand and branding: Issues of theory and representation. Vestnik of Saint Petersburg University. Management 18 (2): 145-174. DOI: https://doi.org/10.21638/11701/ spbu08.2019.201. (In Russian)

Cherubino P., Martinez-Levy A.C., Caratù M., Cartocci G., Di Flumeri G., Modica E., Rossi D., Mancini M., Trettel A. 2019. Consumer behaviour through the eyes of neurophysiological measures: State-of-the-art and future trends. Computational Intelligence and Neuroscience. DOI: $10.1155 / 2019 / 1976847$.

Chicada A. 2019. Cyber security and the brand. Computer Fraud \& Security (9): 6-9.

Chilet J.A., Chen C., Lin Y. 2016. Analyzing social media marketing in the high-end fashion industry using named entity recognition. In: 2016 IEEE/ACM International Conference on Advances in Social Networks Analysis and Mining (ASONAM).

Civil Code of the Russian Federation. Part Four. Federal Institute of Intellectual Property. URL: https:// new.fips.ru/en/documents/civil-code-of-the-russian-federation-4.php (accessed: 28.01.2020).

Collins-Dodd C., Zaichkowsky J. 1999. National brand responses to brand imitation: Retailers versus other manufacturers. Journal of Product \& Brand Management 8 (2): 96-105.

Connor S. 1997. Postmodernist Culture: An Introduction to Theories of the Contemporary. Oxford: Blackwell.

Cordell V., Wongtada N., Kieschnick L. 1996. Counterfeit purchase intentions: Role of lawfulness attitudes and product traits as determinants. Journal of Business Research 35 (1): 41-45.

D’Astous A., Gargouri E. 2001. Consumer evaluations of brand imitations. European Journal of Marketing 35 (1-2): 153-167.

Definition of Marketing, Definitions of Marketing. 2017. American Marketing Association. URL: https://www.ama.org/the-definition-of-marketing-what-is-marketing/ (accessed: 29.01.2020).

Diamond S. 1973. Trademark Problems and How to Avoid Them. Chicago: Crain Communications, Inc.

Dick A., Jain A., Richardson P. 1995. Correlates of store brand proneness: Some empirical observations. Journal of Product and Brand Management 4 (4): 15-22.

Ethics. 2020. American Marketing Association. URL: https://www.ama.org/topics/ethics/ (accessed: 29.01.2020).

Finch A. 1996. When imitation is the sincerest form of flattery: Private label products and the role of intention in determining trade dress infringement. University of Chicago Law Review 6 (3): 1243-1276. 
Felluga D. 2002. Modules on Baudrillard: On Simulation. Introductory Guide to Critical Theory. URL: https://cla.purdue.edu/academic/english/theory/postmodernism/modules/baudrillardsimulation.html (accessed: 01.04.2020).

Floch J.-M. 1990. Sémiotique, Marketing et Communication. Sous les Signes, les Stratégies. Paris: Presses Universitaires de France.

Foxman E., Berger P., Cote J. 1992. Consumer brand confusion: A conceptual framework. Psychology \& Marketing 9 (2): 123-141.

Frankel M. S. 1989. Professional codes: Why, how, and with what impact? Journal of Business Ethics 8 (2-3): 110-111.

Friedman M. P. 1966. Consumer confusion in the selection of supermarket products. Journal of Applied Psychology 50 (6): 529-534.

Hague - The International Design System. WIPO - World Intellectual Property Organization. URL: https://www.wipo.int/hague/en/ (accessed: 28.01.2020).

Hasan R., Siorpaes K., Krummenacher R., Flöck F. 2011. Towards a knowledge diversity model. In: Proceedings of the First International Workshop on Knowledge Diversity on the Web (DiversiWeb 2011), 20 th World Wide Web Conference (WWW 2011). BibSonomy. URL: https://www. bibsonomy.org/bibtex/a7c861f4c4ae6c9fea95813062180090 (accessed: 12.01.2020).

Hietanen J., Murray J. B., Sihvonen A., Tikkanen, H. 2019. Seduced by "fakes": Producing the excessive interplay of authentic/counterfeit from a Baudrillardian perspective. Marketing Theory 20 (1): 23-43.

Hoffler S., Keller K. L. 2003. The marketing advantages of strong brands. Brand Management 10 (6): 421-445.

Howard D., Kerin R., Gengler C. 2000. The effects of brand name similarity on brand source confusion: Implications for trademark infringement. Journal of Public Policy and Marketing 19 (2): 250264.

Huang W.Y., Schrank H., Dubinsky A. J. 2004. Effect of brand name on consumers' risk perceptions of online shopping. Journal of Consumer Behavior 4: 40-50. DOI: https://doi.org/10.1002/cb.156.

Jary M., Wileman A. 2016. Retail Power Plays: From Trading to Brand Leadership. London: Palgrave Macmillan.

Jedlička W. 2009. Packaging Sustainability. New Jersey: Wiley.

Kapferer J.-N. 1995. Stealing brand equity: Measuring perceptual confusion between national brands and "copycat" own-label product. Marketing and Research Today 23 (2): 96-103.

Kashulinsky M., Kovalenko V. 2002. Assassinating a brand. Is it possible to build a business on a copied trademark? URL: http://www.ko.ru/ (accessed: 14.03.2020). (In Russian)

Keller K. L. 2008. Strategic Branding Management: Building, Measuring, and Managing Brand Equity. Upper Saddle River, New Jersey: Prentice Hall.

Kolesnik F., Fukolova J. 2003. What parasites they are! Trade Secret (16): 31-36. (In Russian)

Kotelnikova Z. V. 2008. Face-off products: Why trademark owners turn a blind eye to counterfeiting? Economic Sociology 9 (4): 30-48. (In Russian)

Kühn S., Strelow E., Gallinat J. 2016. Multiple "buy buttons" in the brain: forecasting chocolate sales at point-of-sale based on functional brain activation using fMRI. Neuroimage 136: 122-128. DOI: 10.1016/j.neuroimage.2016.05.021.

Kunz W., Schmitt B., Meyer A. 2011. How does perceived firm innovativeness affect the consumer? Journal of Business Research 64 (8): 816-822.

Lai K. K. Y., Zaichkowsky J. L. 1999. Brand imitation: Do the Chinese have different views? Asia Pacific Journal of Management 16 (2): 179-192.

Labrecque L. I., Milne G. R. 2012. Exciting red and competent blue: The importance of color in marketing. Journal of the Academy of Marketing Sciences 40 (5): 711-727. 
Language Variation: Papers on Variation and Change in the Sinosphere and in the Indosphere in Honour of J. A. Matisoff. 2003. Canberra: The Australian National University.

Laroche M., Papadopoulos N., Heslop L., Bergeron J. 2003. Effects of subcultural differences on country and product differences. Journal of Consumer Behaviour 2 (3): 232-247.

Le Roux A., Bobrie F., Thébault M. 2019. A typology of brand counterfeiting and imitation based on a semiotic approach. Journal of Business Research 69: 349-356.

MacDonald E.K., Sharp B.M. 2000. Brand awareness effects on consumer decision making for a common, repeat purchase product: A replication. Journal of Business Research 48 (1): 5-15.

Madrid - The International Trademark System. WIPO - World Intellectual Property Organization. URL: https://www.wipo.int/madrid/en/ (accessed: 28.02.2020).

Miaoulis G., D’Amato N. 1978. Consumer confusion \& trademark infringement. Journal of Marketing 42 (2): 48-55.

Mitchell V.-W., Walsh G., Yamin M. 2005. Toward a conceptual model of consumer confusion. Advances in Consumer Research 32 (1): 143-150.

Morhart F. M., Herzog W., Tomczak T. 2009. Brand-specific leadership: Turning employees into brand champions. Journal of Marketing 73 (September): 122-142.

Nagasanthi S., Jaseera C.P. 2017. A study on imitation of brand name of convenience goods with special reference to Manjeri, Malappuram district, Kerala. International Journal of Engineering Development and Research 5 (3): 1201-1207.

Nenycz-Thiel M., Romaniuk J. 2011. The nature and incidence of private label rejection. Australian Marketing Journal 19 (2): 93-99.

Nice Agreement Concerning the International Classification of Goods and Services for the Purposes of the Registration of Marks. WIPO - World Intellectual Property Organization. URL: https:// www.wipo.int/treaties/en/classification/nice/index.html (accessed: 28.02.2020).

O’Boyle E. J., Dawson L.E., Jr. 1992. American Marketing Association code of ethics: Instructions for marketers. Journal of Business Ethics 11 (12): 2-23.

Penz E., Stöttinger B. 2003. Brands and counterfeits - what do they have in common? European Marketing Academy Conference, 2003, May. Glasgow, UK: University of Strathclyde.

Phau I., Prendergast G., Chuen L.H. 2001. Profiling brand-piracy-prone consumers: An exploratory study in Hong Kong's clothing industry. Journal of Fashion Marketing and Management 5 (1): $45-55$.

Private brand. Investopedia. URL: https://www.investopedia.com/terms/p/private-brand.asp (accessed: 26.02.2020).

Private label gains across Europe, climbing to all-time highs in seven countries (2018). URL: https:// www.plmainternational.com/news-update (accessed: 26.08.2019)

Sayman S., Hoch S., Raju J. 2002. Positioning of store brands. Marketing Science 21 (4): 378-397.

Sertoğlu A. E., Kavak D. 2017. A more comprehensive view of consumer confusion: Scale development. Journal of International Consumer Marketing 29 (4): 265-276.

Shlyakov A. V. 2016. Economy of postmodern: From products to simulacra. Society: Politics, Economics, Law (5): 90-92. (In Russian)

Starov S. A., Kiriykov S. I. 2016. Managing perceived risks in buying private label products. Brand Management (1): 28-43. (In Russian)

Starov S. A., Zagorsky A. L., Gladkikh I. V., Sumbaieva A. A. 2016. Research of perceived risks toward buying products under private labels of retailing networks. Vestnik of Saint-Petersburg University. Management (2): 3-34. (In Russian)

Sweeney J.C., Soutar G.N., Johnson L.W. 1999. The role of perceived risk in the quality-value relationship: A study in a retail environment. Journal of Retailing 75 (1): 77-105. 
The future of online brand protection. 2019. MarkMonitor Online Barometer. URL: https://sistemaproprietaintellettuale.it/pdf/MarkMonitor_Online_Barometer_Q4-2018.pdf (accessed: 10.03.2020).

The Brand Protection, Content Protection \& Anti-Piracy Glossary. 2020. Digital Brand Protection Glossary. URL: https://www.ustels.com/resources/glossary/ (accessed: 10.03.2020).

Uskov V. V. 2001. Diversity brand analysis. Reclamnie idei (4): 102-104. (In Russian)

Van Horen F., Pieters R. 2012. Consumer evaluation of copycat brands: The effect of imitation type. International Journal of Research in Marketing 29: 246-255.

Veg-Sala T., Roux E. 2014. A semiotic analysis of the extendibility of luxury brands. Journal of Product and Brand Management 23 (2): 103-113.

Walsh G., Mitchell V. 2005. Consumer vulnerability to perceived product similarity problems: Scale development and identification. Journal of Macromarketing 25 (2): 140-152.

Walsh G., Hennig-Thurau T., Mitchell V.-W. 2007. Consumer confusion proneness: Scale development, validation, and application. Journal of Marketing Management 23 (7-8): 697-721.

Walsh G., Mitchell V.-W., Kilian T., Miller L. 2010. Measuring consumer vulnerability to perceived product-similarity problems and its consequences. Journal of Marketing Management 26 (1-2): $146-162$.

Wilson J. M., Kinghorn R. 2016. A total business approach to the global risk of product counterfeiting. The Global Edge Business Review 10 (1): 1-6.

Zagorsky A., Starov S. 2015. Retail Chain Brand Development Stages. Brand Management (1): 2-8. (In Russian)

Zagorsky A. L., Starov S. A., Kiryukov S. I. 2015. Imitation as branding strategy. Brand Management 3 (82): 155-171. (In Russian)

Zaichkowsky J.L. 2010. Consumer involvement. In: Wiley International Encyclopedia of Marketing. DOI: 10.1002/9781444316568. URL: https://onlinelibrary.wiley.com/doi/book/10.1002/ 9781444316568 (accessed: 10.03.2020).

Zaichkowsky J.L., Simpson R. 1996. The effect of experience with a brand imitator on the original brand. Marketing Letters 7 (1): 31-39.

Received: March 16, 2020

Accepted: April 17, 2020

Contact information

Vitaly I. Cherenkov - Dr. Sci. in Economics, Professor; cherenkov@gsom.spbu.ru Sergei A. Starov - Dr. Sci. in Economics, Associate Professor; starov@gsom.spbu.ru Igor V.Gladkikh — PhD, Associate Professor; gladkikh@gsom.spbu.ru

\title{
ИМИТАЦИЯ БРЕНДОВ НА СОВРЕМЕННОМ РЫНКЕ СИМУЛЯКРОВ И ЭТИКА МАРКЕТИНГА
}

\author{
В. И. Черенков, С. А. Старов, И. В. Гладких
}

Санкт-Петербургский государственный университет,

Российская Федерация, 199034, Санкт-Петербург, Университетская наб., 7-9

Для цитирования: Cherenkov V.I., Starov S. A., Gladkikh I. V. 2020. Brand imitation in the modern simulacrum market versus marketing ethics. Вестник Санкт-Петербургского университета. Менеджмент 19 (2): 203-226. http://doi.org/10.21638/11701/spbu08.2020.204

В статье рассмотрены проблемы имитации брендов в специфических условиях экономики постмодерна, когда материальные предметы (товары) фактически замещаются 
их симулякрами (брендами). Особо выделено противоречие между «духом и буквой» Кодекса этики Американской ассоциации маркетинга и практики брендинга. Показано, что бренды, представленные как симулякры, открывают обширные возможности для имитации бренд-лидеров. Продемонстрирована семантическая рамификация терминов «бренд-лидер» и «бренд-имитатор» в англоязычной интернет-среде. Дана типология методов имитации бренд-лидеров с соответствующими примерами и комментариями. Уточнено понятие «заблуждение потребителя», а также систематизированы и аналитически описаны факторы, определяющие влияние имитированных бренд-лидеров на поведение потребителей. Кроме того, в работе кратко обсуждаются правовые аспекты стратегии имитации брендов (проактивные и реактивные). Статья оснащена пояснительными иллюстрациями.

Ключевые слова: бренд-имитатор, бренд-лидер, заблуждение потребителя, проактивная защита брендов, реактивная защита брендов, семантика брендов, семиотика брендов, экономика постмодерна, этика маркетинга.

Статья поступила в редакцию 16 марта 2020 г. Статья рекомендована в печать 17 апреля 2020 г.

Контактная информация

Черенков Виталий Иванович - д-р экон. наук, проф.; cherenkov@gsom.spbu.ru

Старов Сергей Александрович - д-р экон. наук, доц.; starov@gsom.spbu.ru

Гладких Игорь Валентинович - канд. экон. наук, доц.; gladkikh@gsom.spbu.ru 